\title{
Quantifying the impact of climate change on drought regimes using the Standardised Precipitation Index
}

Katie Jenkins ${ }^{1, *}$ and Rachel Warren ${ }^{2}$

\begin{abstract}
The study presents a methodology to characterise short or long-term drought events, designed to aid understanding of how climate change may affect future risk. An indicator of drought magnitude, combining parameters of duration, spatial extent, and intensity, is presented based on the Standardised Precipitation Index (SPI). The SPI is applied to observed (1955-2003) and projected (2003-2050) precipitation data from the Community Integrated Assessment System (CIAS). Potential consequences of climate change on drought regimes in Australia, Brazil, China, Ethiopia, India, Spain, Portugal and the USA are quantified. Uncertainty is assessed by emulating a range of global circulation models to project climate change. Further uncertainty is addressed through the use of a high emissions scenario and a low stabilisation scenario representing a stringent mitigation policy.
\end{abstract}

Climate change was shown to have a larger effect on the duration and magnitude of long-term droughts, and Australia, Brazil, Spain, Portugal and the USA were highlighted as being particularly vulnerable to multi-year drought events, with the potential for drought magnitude to exceed historical experience. The study highlights the characteristics of drought which may be more sensitive under climate change. For example, on average short-term droughts in the USA do not become more intense but are projected to increase in duration. Importantly, the stringent mitigation scenario had limited effect on drought regimes in the first half of the $21^{\text {st }}$ century, showing that adaptation to drought risk will be vital in these regions.

Keywords: Drought, Magnitude, Standardised Precipitation Index, Climate Change, Integrated Assessment Modelling

\section{Introduction: Drought and Climate Change}

Droughts are slow onset, spatially extensive, events that can affect regions for weeks, months or years. Drought can be defined simply as 'a prolonged absence or marked deficiency of

\footnotetext{
${ }^{1}$ Cambridge Centre for Climate Change Mitigation Research (4CMR), Dept. Land Economy, University of Cambridge, Cambridge, CB3 9EP, UK

${ }^{2}$ Tyndall Centre, School of Environmental Sciences, University of East Anglia, Norwich, NR4 7TJ, UK

* Environmental Change Institute, School of Geography and the Environment, University of Oxford, Oxford, OX1 3QY, UK. Email: Katie.jenkins@ ouce.ox.ac.uk; Tel.: +44 01865 275861; Fax: +4401865 275850
} 
precipitation' (IPCC 2007, p.261). Drought can also be defined based on the duration of the precipitation deficit and particular impacts which may evolve over time: meteorological drought relates to a deficit in precipitation from average conditions; hydrological drought implies a departure in surface and sub-surface water supplies from average conditions; agricultural drought is related to the availability of soil moisture to support crop growth; whilst socioeconomic droughts can be caused by human effects on the supply and demand of water resources (Wilhite and Buchannan-Smith 2005).

Droughts are responsible for one of the largest impacts on society of all extreme weather types (EM-DAT 2012), and are an economically important hazard for many countries with agriculture, livestock, forestry, energy, industry, and water sectors all particularly at risk (NDMC 2006a). Consequently, any changes to hydrological systems, such as those caused by drought, will pose a significant risk to society. Evidence suggests that drought events have been increasing in frequency and intensity in some regions over the latter half of the 20th century in response to global climate change (Zhang et al. 2007; Lynch et al. 2008; IPCC 2012). Projections also suggest that drought is likely to be further exacerbated in certain regions under future climate change, including Southern Europe and the Mediterranean, Central Europe, central North America, Central America and Mexico, northeast Brazil and Southern Africa (Sheffield and Wood 2008; Warren et al. 2012; IPCC 2012).

In order to understand how drought events may impact on society and the economy their specific characteristics, such as duration, intensity and spatial extent need to be considered (IPCC 2012). However, the task of accurately and systematically identifying and quantifying individual drought events is not simple. Each drought event is unique and the process of defining drought is a subjective affair related to the overall aims and objectives of the user (Wilhite 2005). Consequently, a large number of indices have been developed for drought analysis in the domains of meteorology, hydrology, and agricultural analysis. However, drought studies often focus on changes in just one or two characteristics of drought such as their frequency or duration (e.g. Wei $\beta$ et al. 2007; Lehner et al. 2006; Burke et al. 2006; Hirabayashi et al. 2008; Blenkinsop and Fowler 2007), whilst ignoring other characteristics which when considered in parallel could contribute to a more robust overall assessment of drought trends, and be useful for assessing economic and social consequences. Representation of drought in terms of both spatial and temporal characteristics has been gaining attention, particularly with respect to historic events, although the lack of application of such methods to the evolution of characteristics under future climate change is noted (Vidal et al. 2012). The IPCC (2012) also 
highlight that a distinction needs to be made between short and long term drought events as the magnitude of change and even the direction of change can vary depending on the timescale employed.

Similarly, uncertainties in drought projections can arise due to the use of different climate models and their underlying parameters and model components, and uncertainties over the future evolution of greenhouse gas emissions (Kirono and Kent 2011). Studies have begun to address such uncertainties by incorporating two or more climate models to investigate the significance for drought projections (e.g. Sheffield and Wood 2008; Burke and Brown 2008), or two or more emission scenarios to investigate the importance of emission trajectories (e.g. Sheffield and Wood 2008; Vasiliades et al. 2009). A common approach is to use emission scenarios, such as those from the IPCC SRES, as proxies for actual mitigation scenarios. One exception is that of Warren et al., (2012) who investigated changing drought regimes in Europe, including for the first time scenarios of policy-induced mitigation options. This development is particularly beneficial if connections are to be made between the physical characteristics of drought and economic and social impacts, and the economic effectiveness of climate policies to mitigate such impacts.

This study complements current literature by developing a methodology to identify and quantify individual drought events based on a range of characteristics. In particular, a comprehensive indicator of drought magnitude is developed which incorporates intensity, duration and spatial extent. Its basis upon the Standardised Precipitation Index (SPI) allows ready distinction to be made between short and longer-term droughts. A second advantage is that the methodology benefits from use of the Community Integrated Assessment System (CIAS). This enables precipitation data to be projected by emulating the behaviour of a range of global circulation models (GCMs) and emission scenarios representing a range of levels of effort to reduce emissions of greenhouse gases in a computationally efficient manner, and also facilitates the explicit modelling of climate policy scenarios.

The first application of this methodology focuses on Australia, Brazil, China, Ethiopia, India, Portugal, Spain, and the USA. These countries were selected as they cover different geographical, climatological, and hydrological regimes; have suffered from serious drought events in the past; are known to suffer from water stress; and are vulnerable to future climate change (Bates et al. 2008). The study provides a quantitative analysis of future drought characteristics; addresses the sensitivity of regional trends in short and longer-term drought to 
the choice of GCM and the emission/stabilisation scenarios employed; and assesses the effectiveness of stringent mitigation in terms of preventing future changes in drought characteristics.

\section{Methodology}

\subsection{The Community Integrated Assessment System (CIAS)}

The integrated assessment model CIAS was used to project future changes in global precipitation regimes and hence drought. CIAS has been designed to assess policy options, avoided damages and uncertainties associated with climate change (Warren et al. 2008). In this application CIAS was driven by emission scenarios, including a greenhouse gas mitigation scenarios provided by E3MG (Energy-Environment-Economy Global Model) (Barker et al. 2006) that results in stabilisation of $\mathrm{CO}_{2}$ at $450 \mathrm{ppm}$ by 2100. Emissions from the IPCC SRES scenarios, which assume no climate change mitigation, are also used. Within CIAS the emission scenarios drive a simple Climate Model (SCM) MAGICC which has been tuned to emulate seven AOGCMs used within the IPCC Third Assessment Report (TAR) so that the user can force the model to emulate the behaviour of any of these (Warren et al. 2008).

CIAS also incorporates the downscaling model ClimGen (Climate Generator) which uses pattern scaling to provide monthly precipitation data, at a $0.5^{\circ}$ resolution for observed (19012002 based on the CRUTS2.1 dataset of Mitchell and Jones (2005)) and future climate (20012100). ClimGen uses simulations from five GCMs available from the World Climate Research Programme's (WCRP's) Coupled Model Intercomparison Project phase 3 (CMIP3) multi-model dataset, each run with up to four SRES scenarios. The different patterns generated allow the range of uncertainty related to the use of different GCMs and emission scenarios to be investigated. Thus, the 'pattern scaling' approach allows the computational simplicity of SCMs and the spatial patterns of GCMs to be combined (Mitchell 2003). The results are interpolated using the ClimGen 'gamma-method' which expresses the precipitation changes seen in the GCM pattern as a fractional change from present day precipitation, and also considers interannual variability independently of mean precipitation changes. The observed inter-annual variability is modified according to changes in the shape parameter of the gamma distribution, which provides a measure of skewness of the distribution, derived from the selected GCM simulation (Warren et al. 2012).

The study focuses on a comparison of observed drought during 1955-2002 with projected drought in the first half of the 21st century (2003 to 2050). The study uses the A1FI SRES 
emission scenario and the E3MG 450ppm $\mathrm{CO}_{2}$ stabilisation scenario, and the GCMs HADCM3, CSIRO2, and ECHAM4. The use of alternative GCMs results in widely differing projections of global changes in precipitation and hence drought. These GCMs were selected as they adequately sample the full range of global precipitation projection outcomes, with ECHAM4 projecting lower precipitation rates than most of other models under climate change, CSIRO2 projecting higher rates than most, and HADCM3 projecting a more common outcome (IPCC 2001, figure 9.3).

\subsection{Identification and quantification of drought events}

The Standardised precipitation Index (SPI), developed by McKee et al. (1993), is used to assess and quantify drought. One advantage of the SPI is that it can be determined for different time periods to allow the dynamics of different types of droughts to be assessed. Secondly, the SPI is a relatively simple to calculate as it only requires precipitation data, yet simple indexes such as the SPI have been shown to perform better than other, often more complex, indexes (e.g. Keyantash and Dracup 2002; Lloyd-Hughes and Saunders 2002; Redmond 2002; Guttman 1999, 1998). This also has benefits as precipitation data can be collected for more sites than other variables such as soil moisture; precipitation is the key variable in drought definitions as all droughts stem from a precipitation deficit; and precipitation data is available for longer time periods than other meteorological data (Byun and Wilhite 1999). The potential advantages of modelling drought using the SPI, and potential use to help guide drought mitigation and adaptation strategies is also reflected in its subsequent uptake in over 60 countries, as well as by the National Drought Mitigation Centre, the National Data Climatic Centre, and across many states in the US (Wu et al. 2005). Furthermore, the application of the SPI to this study is highly desirable as it provides a method for analysing the frequency, duration, intensity and magnitude of drought events.

Two SPI time periods were used: a six month time period (SPI-6), effective at showing changes in precipitation over distinct seasons, and representing agricultural drought, and a twelve month time period (SPI-12), effective at highlighting specific trends and long term changes in annual precipitation patterns, to represent hydrological drought (NDMC 2006b). As in the standard procedure, here the time period $(i)$ was used to create a lagged moving average where each new precipitation value is determined based on the previous $i$ months. As precipitation is not normally distributed for timescales of twelve months or less a gamma distribution has been found to be favourable to the normal distribution (Guttman 1999; Lloyd-Hughes and Saunders 2002). The lagged average monthly precipitation time series is fitted to the gamma function in 
order to determine the relationship of probability to precipitation. The probability of any precipitation data point can then be calculated and used along with an estimate of the inverse normal to calculate the precipitation deviation for a normally distributed probability density function (McKee et al. 1993)(a full description and equations are available in, inter alia., LloydHughes and Saunders (2002)). The resulting output is the SPI value for a given precipitation data point and time period (table 1).

\section{[Table 1]}

Monthly SPI-6 and SPI-12 values were computed for each country of interest. However, as drought will rarely, if ever, affect an entire country (Wilhite 2005) a regional approach has been adopted similar to that of Giorgi and Francisco (2000) who divided all land areas in the World into 21 regions. These regions were selected in order to represent different climate regimes with a manageable number of regions of similar shape. This approach has been widely used in order to provide robust statements of regional climate change (Sheffield and Wood 2008; IPCC 2007b). The regions used for the eight countries in this study (figure one and table two) were based primarily on those defined in the above studies. However, as some of these regions were still very large they were further divided based on country specific climate change reports and information on precipitation regimes of the countries. This enabled a more disaggregated study of drought events to be conducted and aimed to minimise biases in spatial averaging when identifying drought events.

[Figure 1]

[Table 2]

Bar charts of average monthly SPI values were created for each of the regions for the baseline and future period to enable drought events to be visually identified and compared. As observed precipitation data from 1955-2002 were used to create future precipitation time-series data in ClimGen, with the natural variability in mean monthly precipitation trends for 1955-2002 assumed to repeat unchanged during the period 2003-2050, any changes seen in the precipitation distribution and subsequently SPI data could be attributed (in the model) to anthropogenic climate change. A drought was defined as any period when the SPI value was $\leq-$ 1.50 representing severe or extremely dry conditions (table one). The drought start date was defined as the first month in which the SPI became negative and the drought end date was defined as the first month in which the SPI became positive again. The SPI value of -1.50 was 
used as the threshold to define drought so that the emphasis of the study was on the effects of severe and extreme drought as it was assumed that larger magnitude events will result in the most severe consequences for economies and society; it was assumed that these events would be difficult to cope with compared to more moderate drought events, even if future adaptation takes place; and there is some evidence to suggest that at a global level the frequency of severe and extreme drought events will increase whilst the number of moderate drought events would remain stable (Burke et al. 2006).

For countries with multiple regions the same drought event could potentially encompass two or more regions. To avoid a large-scale drought being counted as multiple, smaller events when regional drought dates coincided for a given country drought maps were created using GIS to identify if they were separate drought events or a single event encompassing multiple regions. For each drought event identified the SPI values for the drought-affected cells (i.e. cells that had a SPI value of less than 0.0 ) were analysed.

McKee et al., (1993, p.2) define drought magnitude as the absolute sum of the SPI values across the duration of the recorded drought. This has been modified in this study to also encompass the spatial extent of each event. Equation one is used to calculate the Monthly Drought Magnitude (MDM) of the affected region for each drought month where $k=$ drought month, $n=$ total number of grid cells affected in month $k$, and $j=$ grid cells affected in month $k$. Total Drought Magnitude (TDM) is then calculated using equation two, which sums the MDM over the duration of the recorded drought, where $m=$ total number of months affected by drought.

$$
\begin{gathered}
M D M_{\mathrm{k}}=-\left(\sum_{j=1}^{\mathrm{n}} S P I_{j}\right) \\
T D M=\left(\sum_{\mathrm{k}=1}^{\mathrm{n}} M D M_{\mathrm{k}}\right)
\end{gathered}
$$

The drought intensity can be inferred directly from the SPI value. Peak intensity is defined by McKee et al., (1993) as the minimum SPI value reached during the drought event. McKee et al applied this to monthly station (point) data that does not have a spatial aspect and so in this study the definition of peak intensity was modified. Equation three has been used to calculate the monthly Average Intensity $(A I)$ of each drought event. The Peak Intensity $(P I)$ is then defined as the minimum monthly $A I$ recorded during the drought event. 


$$
A I_{k}=\left(\sum_{j=1}^{n} S P I_{j}\right) / n
$$

Eq. 3

\section{Results}

Figures 2a-d display the projected change in average drought frequency, duration, peak intensity, and magnitude from 1955-2002 to 2003-2050 for each country (full tables of results are presented in tables three and four). Drought results for each country and scenario are presented as averages for the 1955-2002 and 2003-2050 periods, as although the method provides quantitative estimates of individual drought events it does not aim to explicitly present projections of individual events, their exact timing, or location. Instead the results reflect a broader picture of changes that may occur under future climate change, although it is important to bear in mind that this averaging masks some large variability in the characteristics of individual drought events. Regional level results are presented in tables A1 to A10 for Australia, Brazil, China, India, and the USA, in the supplementary material.

[Figure 2a-d]

[Table 3 and 4]

Results for Australia suggest increasing drought frequency for both SPI-6 and SPI-12 drought events. Average drought magnitude was projected to increase by 6-21\% for SPI-6 droughts, but is more mixed using SPI-12, ranging from $-6 \%$ to $+64 \%$ depending on the GCM used. In all scenarios the average peak intensity was projected to increase (i.e. the SPI value became more negative), suggesting the potential for more intense droughts in the future. Based on the country regions, projections using ECHAM4 and HADCM3 suggested an increase in drought frequency in north-west and particularly south-west Australia. This finding is in agreement with Christensen et al., (2007) who project increased drought in Southern Australia, and a report by CSIRO and the Australian BoM (2007) who projected an increase in drought, particularly in the south-west. Conversely, results of this analysis simulated with CSIRO2 suggested a decline in drought frequency in south-west Australia, although the duration, intensity and magnitude of those events which do occur increase from the observed period.

The general pattern of change for Brazil is for an increase in drought frequency, intensity, duration and magnitude. Drought magnitude is projected to change by between $-38 \%$ to $+165 \%$ for SPI-6 droughts and by $25 \%$ to $282 \%$ for SPI-12 droughts suggesting that SPI-12 drought events are likely to become particularly severe in the future. Additionally, average drought duration of SPI-12 events is projected to increase by 30 months, with some events projected to 
last over seven years. Thus, even in the first half of the $21^{\text {st }}$ century climate change may induce more multi-year drought events. Regionally, projections using ECHAM4 showed an increase in drought in northern Brazil, particularly the northeast with little change seen in the south. Similar projections were seen using HADCM3 although a greater increase in drought events was seen in the northwest compared to northeast Brazil. Whilst there are few regional precipitation studies for Brazil these findings are consistent with those of Marengo et al., (2009) who suggest that northeast Brazil and eastern Amazonia could suffer drier conditions from 1961-1990 to 20712100, and Li et al., (2008) who highlighted a move towards more intense drought in the region in the future.

Results for China suggest average frequency and duration may well decrease for SPI-6 droughts whilst there is little change in the intensity and magnitude in the first half of the $21^{\text {st }}$ century. Using SPI-12 frequency and duration remained stable whilst magnitude and intensity decrease. These broad findings are consistent with other studies (e.g. Christensen et al., (2007) and Kim and Byun (2009) who projected increases in precipitation for most parts of Asia leading to a decrease in drought frequency and duration). However, as there was only one drought event visible in the future projections it is difficult to make a robust statement about the spatial pattern of change in drought events for China, although the results do indicate that China is likely to become wetter in the first half of the $21^{\text {st }}$ century. In all scenarios this drought event occurred in north-west China. In comparison, other studies suggest that there will be a north-south divide with southern China becoming drier and northern china becoming wetter by the 2050s or later (Hirabayashi et al. 2008; Gao et al. 2008).

There was a large range in the projections of drought for Ethiopia depending on the GCM used, particularly for SPI-12 drought events where there was less consistency in the direction of change. In some scenarios there is an increase in drought frequency although other drought characteristics become less severe. In other cases, droughts occur less frequently but when they do occur they are projected to be of greater magnitude than historic events. It is difficult to ascertain robust trends for drought characteristics in Ethiopia, although the general pattern of declining drought duration and magnitude are consistent with the findings of Christensen et al., (2007) who state that there is likely to be an increase in annual mean rainfall in east Africa in the $21^{\text {st }}$ century, particularly in the dry season.

Average drought frequency, duration, magnitude and intensity were projected to decline in India by the first half of the $21^{\text {st }}$ century, with a consistent trend in the sign of change across the six 
scenarios. These results are consistent with the findings of Christensen et al., (2007) for South Asia who project a slight decrease in precipitation in the dry season but an increase in precipitation for the rest of the year. At a regional scale a decrease in drought frequency was projected for all regions yet as so few events were visible, including in the observed data, it is hard to make a robust statement on regional changes. For example, Rupa Kumar et al., (2006) found increasing precipitation trends for India, particularly over the west coast and northeast India using the regional PRECIS model. However, at a state level they find that central Indian states are more prone to severe rainfall activities whilst there are slight declines in annual rainfall for three states in southern and northeast India.

In Spain average drought duration, magnitude, and intensity all increase in the future with good consistency in the model results. For SPI-6 droughts the average magnitude is projected to increase by 18 to $143 \%$ in the first half of the $21^{\text {st }}$ century. For SPI-12 droughts the average magnitude is projected to increase by 96 to $341 \%$, highlighting that both short and longer-term drought events are likely to become more severe under future climate change. Conversely, there is a slight decline in the frequency of SPI-12 droughts which can be linked to the increasing duration of the events which do occur. The effect of climate change on drought trends in Portugal was less consistent with more variability in the direction of change. However, average results suggest that drought duration, magnitude and intensity all increase in the future. As with Spain, drought frequency was projected to increase for SPI-6 droughts but average results for SPI-12 droughts suggested no change. The findings for Spain and Portugal are consistent with the consensus reached by many other modelling studies that there will be a decline in precipitation in the Mediterranean with increased drought frequency and duration (e.g. Warren et al. 2012; Blenkinsop and Fowler 2007).

Results for the USA were mixed with less model consistency in the direction of change. Projections suggest a slight increase in drought frequency and duration of SPI-6 events. For SPI-12 droughts frequency was projected to decline slightly whilst duration was projected to increase on average by 10 months. The change in average drought intensity also varied depending on the SPI time period used with a decrease in intensity seen for SPI-6 droughts and an increase in intensity for SPI-12 droughts. Different regional trends were seen depending on the scenario and SPI time-period used, with no consistent pattern seen across the models. For example, results generated using CSIRO2 suggest drought characteristics may become more severe in central and south-west USA, although the frequency of events remains stable. Results using ECHAM4 suggest a decline in SPI-6 drought frequency in the south-west, whilst no 
droughts are projected to occur in this region using SPI-12. Such inter-model uncertainties have been highlighted by other regional studies conducted for the USA (e.g. NARCCAP2007) although some common features are identified including a general drying trend in the southwest in winter, wetter conditions in the north-east, and drying across the western USA during summer.

The above discussion highlights how climate change could affect future drought regimes in Australia, Brazil, China, Ethiopia, India, Portugal, Spain and the USA. The results presented are in line with projections reported by the IPCC (Christensen et al. 2007), as well as other modelling studies reviewed. However, the uncertainty seen when using different scenarios can be large and this uncertainty increases as the SPI time period increases from SPI-6 to SPI-12 and as the focus shifts from a country to regional level. For some countries there were significant differences in the direction of change in the trend of drought parameters under future climate change. Figures 3a-f illustrate that the use of emission scenarios with or without stringent climate mitigation has little effect upon future drought projections during the first half of the $21^{\text {st }}$ century. Comparatively, results generated using emulations of the different GCMs exhibited much larger variability. The graphs also highlight the larger effect of climate change on the magnitude of SPI-12 droughts.

[Figure 3a-f]

\section{Discussion}

The study suggests that climate change in the first half of the $21^{\text {st }}$ century could result in worsening drought regimes in Australia (particularly in the south-west), Brazil (particularly in the northeast and northwest), Portugal, and Spain. The effect of climate change on average drought conditions in the USA was more variable depending on the region and the climate scenario used. However, results suggest that changing trends in drought characteristics, particularly for long-term drought events, are likely to be negative. Conversely, results for China, Ethiopia and India suggest that climate change may well cause increased precipitation which could mitigate the frequency and magnitude of droughts, with very few, if any, severe and extreme drought events projected for 2003-2050. Whilst the frequency of SPI-12 droughts generally decrease climate change is likely to have a larger effect on their duration and magnitude, and for Portugal, Spain and the USA their intensity. As SPI-12 can be tied to hydrological drought (NDMC 2006b) it suggests that water resources will be very vulnerable to climate change. Furthermore, results indicate an increase in multi-year drought events in 
Australia, Brazil, Spain, Portugal and the USA, which will be harder to cope with due to their compounding effects and continued drain on resources and adaptive strategies.

The study aimed to account for some of the uncertainties that arise when modelling future precipitation. As the study focuses on the first half of the $21^{\text {st }}$ century there was little variability seen between results generated using the A1FI and 450ppm scenarios. As such, the implementation of a stringent mitigation policy is projected to have limited effect on worsening drought conditions from 2003-2050 compared to the A1FI scenario, whilst it should be noted that it has been shown that mitigation would greatly reduce changes in drought regime in the second half of the $21^{\text {st }}$ century, at least in Europe (Warren et al. 2012). Instead, much of the uncertainty in future projections of drought events, including the direction of change, was linked to the GCM used, consistent with Goodess et al., (2003) who reports that for the early $21^{\text {st }}$ century inter-model variability tends to be greater than inter-scenario variability. It is anticipated that the GCMs used in this study (ECHAM4, HADCM3 and CSIRO2) provide a good representation of the scale of model uncertainty and is advantageous as it has been noted that assessments of future drought events have traditionally only used one GCM (Blenkinsop and Fowler 2007).

In terms of the methodological approach the study used pre-defined country regions to overcome issues of spatial averaging when assessing future drought events. However, the coarse regions were still relatively large and in the case of Ethiopia, Portugal, and Spain results were analysed at a country level only. Future research would benefit from using smaller, pre-defined geographical regions or state boundaries. This would be particularly beneficial for large countries with varying regional precipitation regimes such as China and the USA. However, it is important to note that the methodology would be less beneficial for identifying drought at smaller spatial scales as it does not represent small-scale weather processes, local topography, land-use, or hydrological systems such as rivers, catchment areas, dams, or reservoirs that would be required for a drought analysis at this scale.

Furthermore, the use of the SPI and its reliance on precipitation data reflects meteorological drought, with a link to hydrological and agricultural drought represented via the use of different SPI time-periods used in the study. An issue with many drought indexes is that they have been developed with a focus on larger-scale meteorological and/or hydrological drought, and less focus on vegetation responses required to provide more application to smaller scale agricultural drought (Mu et al. 2013). For example, the Drought Severity Index utilises satellite-derived 
evapotranspiration, potential evapotranspiration, and the normalized difference vegetation index (NDVI) to detect and monitor droughts on a global basis. The use of more spatially detailed satellite data can be useful for operational water supply assessments at a community level, and is at a scale more suitable for water resource applications (ibid.).

Whilst a key component of this research has been comparing past and future drought regimes, in applying the SPI to future projections of drought it is also important to consider additional consequences of climate change. Whilst precipitation may be the primary factor in drought occurrence, under climate change high temperatures may have an increasingly large effect on drought events. This is a particularly important issue as it is projected that annual average temperatures increase in all of the countries assessed in this study in the $21^{\text {st }}$ century (IPCC 2007b). This already appears to be the case in Australia where recent drought events have not been drier than $20^{\text {th }}$ century droughts but have been accompanied by higher temperatures (CSIRO and Australian BoM 2007). Changes in temperature, radiation, atmospheric humidity, and wind speed can also affect the amount of evaporation and further exaggerate effects of decreased precipitation on surface water and run-off which could also be important for future drought projections (IPCC 2007b; Trenberth and Guillemot 1996; Sheffield and Wood 2011). As the results of this study are based on precipitation data only they may well be underestimated. Furthermore, potential feedback effects have not been considered. For example, the potential for large-scale droughts to reduce Net Primary Production weakening the terrestrial carbon sink (Zhao and Running 2010; Mu et al. 2013). Consequently, the magnitude of the terrestrial carbon sink could be overestimated if extreme climate events are not considered in future projections.

As the size and even direction of change in drought characteristics can vary depending on the timescale employed results were presented for a six month (SPI-6) and a twelve month (SPI-12) time period. The results highlighted that climate change is likely to have a larger effect on the duration and magnitude of longer-term SPI-12 droughts representing an increased risk to hydrological systems and water resources. For example, the change in average drought magnitude for Brazil was more than three times as great using SPI-12 compared to SPI-6. One explanation may be that SPI-12 reflects an average annual decline in precipitation, although this decline may not be evenly distributed over seasons. In comparison, the SPI-6 index will be more sensitive to shorter-term variability in the volume and intensity of precipitation - something which has been projected to increase under future climate change (IPCC 2007b). Regions projected to suffer more drought events in the future may also be at risk from heavy precipitation or flood events (Hirabayashi et al. 2008). The timing of drought events is also an 
important factor to consider especially for assessing the type and scale of economic and social impacts which may occur. This study did not take into consideration particular seasons affected by drought, or indeed, if there were seasonal changes in the timing of drought events.

Finally, it is important to highlight that the study focuses on consequences of climate change on meteorological drought and does not consider other socio-economic factors that may change in the first half of the $21^{\text {st }}$ century such as increasing populations increasing the demand for water, or increased extraction of groundwater which could exacerbate drought. Conversely, future adaptation to drier conditions (i.e. increased water storage capacity, or desalination) may offset some of this risk.

\section{Conclusion}

The new drought magnitude characteristic was found to provide a comprehensive measure of drought by combining information on intensity, duration and spatial extent of drought.

Consequently it could provide a useful indicator for defining drought events in the future and reflecting the complex evolution of an event over space and time. Its basis in the SPI indicator means that it is simple to calculate as it is based on precipitation data alone. The overall trends in drought projections presented by this study showed good consistency with existing literature in this area, particularly when compared at the national level.

The study highlighted that south-west Australia, northeast and north-west Brazil, Portugal, and Spain are particularly at risk from worsening drought conditions in the first half of the $21^{\text {st }}$ century. Results for the USA were more variable depending on the region and the climate scenario used. However, overall trends in drought characteristics, particularly for longer-term SPI-12 droughts, are likely to be negative. Projections for China, Ethiopia and India suggest that climate change may well increase precipitation over the first half of the $21^{\text {st }}$ century, potentially mitigating drought events. Climate change was shown to have a larger effect on the duration and magnitude of longer-term droughts, representing increased risk to hydrological systems and water resources. Australia, Brazil, Spain, Portugal and the USA were shown to be particularly vulnerable to multi-year drought events.

The study highlighted that the implementation of a stringent mitigation policy is projected to have limited effect on drought and its effects, in the eight countries studied, in 2003-2050. However, during this time drought magnitude could exceed current historical experience and surpass existing thresholds of social and economic resilience. As such, drought risk 
management plans and adaptive strategies will become especially important in the short to medium-term. Furthermore, the methodology provides a framework to quantify and link individual drought events to reported economic and social impacts facilitating the creation of drought damage functions. Such damage functions can be used to investigate the consequences of drought risk in terms of economic and social impacts (Jenkins 2012, 2013).

The methodology was devised in order to facilitate application across a wide range of countries, regions, time-scales, and climate scenarios, and to address current gaps in research such as the need to consider drought over multiple timescales and to consider multiple characteristics of drought in a single framework. The link with CIAS allows model uncertainty to be considered as well as an assessment of policy-induced mitigation options. Consequently, the methodology could provide information for policy makers and stakeholders with an interest in longer-term regional and national drought risk management, as it can incorporate the potential effects and uncertainties of climate change and climate change mitigationstrategies on future drought regimes.

\section{References}

Barker T, Pan H, Kohler J, Warren R, Winne S (2006) Avoiding Dangerous Climate Change by Inducing Technological Progress: Scenarios Using a Large-Scale Econometric Model. In: Schellnhuber HJ, Cramer W, Nakicenovic N, Wigley T, Yohe G (eds) Avoiding Dangerous Climate Change. Cambridge University Press, Cambridge, pp 361-372

Bates BC, Kundzewicz ZW, Wu S, Palutikof J (eds) (2008) Climate Change and Water. Technical Paper of the Intergovernmental Panel on Climate Change. IPCC Secretariat, 210pp, Geneva

Blenkinsop S, Fowler HJ (2007) Changes in European drought characteristics projected by the PRUDENCE regional climate models. International journal of climatology 27:15951610

Burke EJ, Brown SJ (2008) Evaluating Uncertainties in the Projection of Future Drought. Journal of Hydrometeorology 9 (2):292-299. doi:10.1175/2007jhm929.1

Burke EJ, Brown SJ, Christidis N (2006) Modeling the Recent Evolution of Global Drought and Projections for the Twenty-First Century with the Hadley Centre Climate Model. Journal of Hydrometeorology 7:1113-1125

Byun H-R, Wilhite D (1999) Objective quantification of drought severity and duration. American Meteorological Society 12:2747-2756

Christensen JH, Hewitson B, Busuioc A, Chen A, Gao X, Held I, Jones R, Kolli RK, Kwon WT, Laprise R, Rueda VM, Mearns L, Menéndez CG, Räisänen J, Rinke A, Sarr A, Whetton P (2007) Regional Climate Projections. In: Climate Change 2007: The Physical Science Basis. Contribution of Working Group I to the Fourth Assessment Report of the Intergovernmental Panel on Climate Change. In: Solomon S, Qin D, Manning M et al. (eds). Cambridge University Press, Cambridge, pp 847-945

CSIRO, Australian BoM (2007) Climate Change in Australia - Technical Report. Projections developed by CSIRO and the Australian BoM for the Australian Climate Change Science Programme. 
EM-DAT (2012) EM-DAT: The OFDA/CRED International Disaster Database. Université Catholique de Louvain - Brussels - Belgium. www.em-dat.net

Gao X, Shi Y, Song R, Giorgi F, Wang Y, Zhang D (2008) Reduction of future monsoon precipitation over China: comparison between a high resolution RCM simulation and the driving GCM. Meteorology and Atmospheric Physics 100:73-86

Giorgi F, Francisco R (2000) Uncertainties in regional climate change prediction: a regional analysis of ensemble simulations with the HADCM2 coupled AOGCM. Climate Dynamics 16:169-182

Goodess CM, Osborn TJ, Hulme M (2003) The identification and evaluation of suitable scenario development methods for the estimation of future probabilities of extreme weather events. Tyndall Centre for Climate Change Research Technical Report 4. Tyndall Centre for Climate Change Research, Norwich

Guttman NB (1998) Comparing the Palmer Drought Index and the Standardized Precipitation Index. Journal of the American Water Resources Association 34 (1):113-121

Guttman NB (1999) Accepting the Standardized Precipitation Index: A Calculation Algorithm. Journal of the American Water Resources Association 35 (2):311-322

Hirabayashi Y, Kanae S, Emori S, Oki T, Kimoto M (2008) Global projections of changing risks of floods and droughts in a changing climate. Journal of Hydrological Sciences 53 (4):754-772

IPCC (2001) Climate change 2001: The Scientific Basis. Contribution of Working Group I to the Third Assessment Report of the Intergovernmental Panel on Climate Change [Houghton, J.T., Y. Ding, D.J. Griggs, M. Noguer, P.J. van der Linden, X. Dai, K. Maskell, and C.A. Johnson (eds.)]. Cambridge University Press, Cambridge, UK

IPCC (2007) Climate Change 2007: The Physical Science Basis. Contribution of Working Group I to the Fourth Assessment Report of the Intergovernmental Panel on Climate Change [Solomon, S., D. Qin, M. Manning, Z. Chen, M. Marquis, K.B. Averyt, M. Tignor and H.L. Miller (eds.)], vol 1. Cambridge University Press, Cambridge, United Kingdom and New York, NY, USA

IPCC (2007b) Climate Change 2007: Impacts, Adaptation and Vulnerability. Contribution of Working Group II to the Fourth Assessment Report of the Intergovernmental Panel on Climate Change [M.L. Parry, O.F. Canziani, J.P. Palutikof, P.J. van der Linden and C.E. Hanson (eds.)], vol 2. Cambridge University Press, Cambridge, United Kingdom and New York, NY, USA

IPCC (ed) (2012) Managing the Risks of Extreme Events and Disasters to Advance Climate Change Adaptation. A Special Report of Working Groups I and II of the Intergovernmental Panel on Climate Change. Cambridge University Press, Cambridge, UK

Jenkins K (2012) Modelling the economic and social consequences of drought under future projections of climate change. Dissertation. University of Cambridge, Avaliable at: http://www.dspace.cam.ac.uk/handle/1810/242439

Jenkins K (2013) Indirect economic losses of drought under future projections of climate change: a case study for Spain. Natural Hazards 69 (3):1967-1986. doi:10.1007/s11069013-0788-6

Keyantash J, Dracup JA (2002) The Quantification of Drought: An Evaluation of Drought Indices. Bulletin of the American Meteorological Society 83 (8):1167-1180

Kim D-W, Byun H-R (2009) Future pattern of Asian drought under global warming scenario. Theoretical and Applied Climatology 98:137-150

Kirono DGC, Kent DM (2011) Assessment of rainfall and potential evaporation from global climate models and its implications for Australian regional drought projection. International journal of climatology 31 (9):1295-1308. doi:10.1002/joc.2165

Lehner B, Döll P, Alcamo J, Henrichs T, Kaspar F (2006) Estimating the impact of global change on flood and drought risks in Europe: A continental, integrated analysis. Climatic Change 75:273-299 
Li W, Fu R, Juárez RIN, Fernandes K (2008) Observed change of the standardized precipitation index, its potential cause and implications to future climate change in the Amazon region. Philosophical Transactions of the Royal Society B: Biological Sciences 363 (1498):1767-1772. doi:10.1098/rstb.2007.0022

Lloyd-Hughes B, Saunders MA (2002) A Drought Climatology for Europe. International journal of climatology 22:1571-1592

Lynch A, Nicholls N, Alexander L, Griggs D (2008) Garnaut Climate Change Review. Defining the impacts of climate change on extreme events. Submission Report commissioned by the Garnaut Climate Change Review. Monash University,

Marengo JA, Jones R, Alves LM, Valverde MC (2009) Future change of temperature and precipitation extremes in South America as derived from the PRECIS regional climate modeling system. International Journal of Climatology 29 (15):2241-2255

McKee TB, Doesken NJ, Kleist J The Relationship of Drought Frequency and Duration to Time Scales. In: Eighth Conference on Applied Climatology, 17-22 January 1993, Anaheim, California, 17-22 January 1993 1993. p 6

Mitchell TD (2003) Pattern Scaling: An Examination of the Accuracy of the Technique for Describing Future Climates. Climatic Change 60:217-242

Mitchell TD, Jones PD (2005) An Improved Method of Constructing a Database of Monthly Climate Observations and Associated High-Resolution Grids. International journal of climatology 25:693-712

Mu Q, M. Z, S. KJ, N. M, W. RS (2013) A Remotely Sensed Global Terrestrial Drought Severity Index. Bulletin of the American Meteorological Society 94 (1):83-98

NARCCAP (North American Regional Climate Change Assessment Program) (2007) Climate Change Results. University Corporation for Atmospheric Research Accessed 14th July 20102010

NDMC (2006a) Impacts of Droughts. Avaliable at: http://drought.unl.edu/Planning/Impacts.aspx. Accessed 9th June 2010,

NDMC (2006b) Interpretation of SPI Maps.

Redmond KT (2002) The Depiction of Drought. Bulletin of the American Meteorological Society 83 (8):1143-1148

Rupa Kumar K, Sahai AK, Kumar KK, Patwardhan SK, Mishra PK, Revadekar JV, Kamala K, Pant GB (2006) High-resolution climate change scenarios for India for the 21st century. Current Science 90 (3):334-345

Sheffield J, Wood E, F. (2008) Projected changes in drought occurrence under future global warming from multi-model, multi-scenario, IPCC AR4 simulations. Climate Dynamics 31:79-105

Sheffield J, Wood E, F. (2011) Drought: Past Problems and Future Scenarios. Earthscan, London

Trenberth KE, Guillemot CJ (1996) Physical Processes Involved in the 1988 Drought and 1993 Floods in North America. Journal of Climate 9 (6):1288-1298. doi:10.1175/15200442(1996)009<1288:ppiitd>2.0.co;2

Vasiliades L, Loukas A, Patsonas G (2009) Evaluation of a statistical downscaling procedure for the estimation of climate change impacts on droughts. Natural Hazards and Earth System Sciences 9 (3):879-894. doi:10.5194/nhess-9-879-2009

Vidal JP, Martin E, Kitova N, Najac J, Soubeyroux JM (2012) Evolution of spatio-temporal drought characteristics: validation, projections and effect of adaptation scenarios. Hydrol Earth Syst Sci Discuss 9:1619-1670

Warren R, S. de la Nava Santos, Arnell NW, Bane M, Barker T, Barton C, Ford R, Füssel HM, Hankin RKS, Klein R, Linstead C, Kohler J, Mitchell TD, Osborn TJ, Pan H, Raper SCB, Riley G, Schellnhüber HJ, Winne S, Anderson D (2008) Development and illustrative outputs of the Community Integrated Assessment System (CIAS), a multiinstitutional modular integrated assessment approach for modelling climate change. 
Environmental Modelling Software 23 (5):592-610.

doi:http://dx.doi.org/10.1016/j.envsoft.2007.09.002

Warren R, Yu R, Osborn TJ, de la Nava Santos S (2012) European drought regimes under mitigated and unmitigated climate change: application of the Community Integrated Assessment System (CIAS). Climate Research 51 (2):105-123

Wei $\beta$ M, Flörke M, Menzel L, Alcamo J (2007) Model-based scenarios of Mediterranean droughts. Advances in Geosciences 12:145-151

Wilhite D, Buchannan-Smith M (2005) Drought as Hazard: Understanding the Natural and Social Context. In: Wilhite D (ed) Drought and Water Crises: Science, Technology and Management Issues. Taylor \& Francis, London, p 399

Wilhite DA (ed) (2005) Drought and Water Crises: Science, Technology, and Management Issues. Taylor \& Francis, London

Wu H, Hayes MJ, Wilhite DA, Svoboda MD (2005) The effect of the length of record on the standardized precipitation index calculation. International Journal of Climatology 25 (4):505-520

Zhang X, Zwiers FW, Hegerl GC, Lambert FH, Gillett NP, Solomon S, Stott PA, Nozawa T (2007) Detection of human influence on twentieth-century precipitation trends. Nature 448 (7152):461-465

Zhao M, Running SW (2010) Production from 2000 Through 2009 Drought-Induced Reduction in Global Terrestrial Net Primary. Science 329:940-943

\section{Figure Captions}

Fig 1: Regions assessed in this study

Fig 2a-d: Change in drought characteristics from 1955-2002 to 2003-2050 for a) frequency, $b$ ) duration, c) peak intensity, and d) magnitude. Black crosses indicate mean values (left panels: SPI-6 drought events, right panels: SPI-12 drought events).

Fig 3a-f: Average drought magnitude for 1955-2002 and 2003-2050. Results are generated for the SPI-6 and SPI-12 time-periods using the AIFI and 450ppm scenarios and the GCMs ECHAM4, HADCM3 and CSIRO2.

\begin{tabular}{|c|c|}
\hline SPI Value & Category \\
\hline $2.00>$ & Extremely moist \\
\hline $1.50-1.99$ & Severely moist \\
\hline $1.00-1.49$ & Moderately moist \\
\hline$-0.99-0.99$ & Near Normal \\
\hline$-1.00--1.49$ & Moderately dry \\
\hline$-1.50--1.99$ & Severely dry \\
\hline$-2.00<$ & Extremely dry \\
\hline
\end{tabular}

Table 1: SPI Categories. Source: McKee et al., (1993) 


\begin{tabular}{|c|c|c|c|}
\hline Name & Acronym & Latitude $\left(^{\circ}\right)$ & Longitude $\left(^{\circ}\right)$ \\
\hline Northwest Australia & NW-AUS & $27.75 \mathrm{~S}-10.25 \mathrm{~S}$ & $112.75 \mathrm{E}-138.25 \mathrm{E}$ \\
\hline Southwest Australia & SW-AUS & $43.75 \mathrm{~S}-28.25 \mathrm{~S}$ & $114.25 \mathrm{E}-138.25 \mathrm{E}$ \\
\hline Northeast Australia & NE-AUS & $27.75 \mathrm{~S}-10.25 \mathrm{~S}$ & $138.75 \mathrm{E}-153.75 \mathrm{E}$ \\
\hline Southeast Australia & SE-AUS & $43.75 \mathrm{~S}-28.25 \mathrm{~S}$ & $138.75 \mathrm{E}-153.75 \mathrm{E}$ \\
\hline Northwest Brazil & NW-BRA & $15.75 \mathrm{~S}-4.25 \mathrm{~N}$ & $73.75 \mathrm{~W}-50.25 \mathrm{~W}$ \\
\hline Northeast Brazil & NE-BRA & $15.75 \mathrm{~S}-0.25 \mathrm{~N}$ & $49.75 \mathrm{~W}-34.75 \mathrm{~W}$ \\
\hline Southern Brazil & S-BRA & $33.25 \mathrm{~S}-16.25 \mathrm{~S}$ & $57.75 \mathrm{~W}-38.75 \mathrm{~W}$ \\
\hline Northwest China & NW-CH & $36.25 \mathrm{~N}-49.25 \mathrm{~N}$ & $74.25 \mathrm{E}-100.25 \mathrm{E}$ \\
\hline Southwest China & SW-CH & $22.25 \mathrm{~N}-35.75 \mathrm{~N}$ & $79.25 \mathrm{E}-100.25 \mathrm{E}$ \\
\hline Northeast China & NE-CH & $32.75 \mathrm{~N}-50.75 \mathrm{~N}$ & $100.75 \mathrm{E}-119.75 \mathrm{E}$ \\
\hline Southeast China & SE-CH & $18.25 \mathrm{~N}-32.25 \mathrm{~N}$ & $100.75 \mathrm{E}-122.75 \mathrm{E}$ \\
\hline North-Northeast China & NNE-CH & $38.75 \mathrm{~N}-53.25 \mathrm{~N}$ & $120.25 \mathrm{E}-134.75 \mathrm{E}$ \\
\hline Ethiopia & ETH & $3.75 \mathrm{~N}-14.25 \mathrm{~N}$ & $33.75 \mathrm{E}-47.75 \mathrm{E}$ \\
\hline Northwest India & NW-IND & $18.75 \mathrm{~N}-35.75 \mathrm{~N}$ & $68.25 \mathrm{E}-79.75 \mathrm{E}$ \\
\hline Northeast India & NE-IND & $18.75 \mathrm{~N}-35.75 \mathrm{~N}$ & $80.25 \mathrm{E}-97.25 \mathrm{E}$ \\
\hline Southern India & S-IND & $8.25 \mathrm{~N}-18.35 \mathrm{~N}$ & $72.75 \mathrm{E}-84.25 \mathrm{E}$ \\
\hline Spain & SPA & $36.25 \mathrm{~N}-43.75 \mathrm{~N}$ & $9.25 \mathrm{~W}-3.25 \mathrm{E}$ \\
\hline Portugal & POR & $36.75 \mathrm{~N}-42.25 \mathrm{~N}$ & $9.25 \mathrm{~W}-6.75 \mathrm{~W}$ \\
\hline North-West USA & NW-USA & $40.75 \mathrm{~N}-48.75 \mathrm{~N}$ & $124.75 \mathrm{~W}-103.25 \mathrm{~W}$ \\
\hline South-West USA & SW-USA & $29.75 \mathrm{~N}-40.25 \mathrm{~N}$ & $124.25 \mathrm{~W}-103.25 \mathrm{~W}$ \\
\hline Central USA & C-USA & $26.25 \mathrm{~N}-48.75 \mathrm{~N}$ & $102.75 \mathrm{~W}-84.75 \mathrm{~W}$ \\
\hline Eastern USA & E-USA & $24.75 \mathrm{~N}-47.25 \mathrm{~N}$ & $84.25 \mathrm{~W}-66.75 \mathrm{~W}$ \\
\hline
\end{tabular}

Table 2: Study regions by Latitude and Longitude (defined using the geographic coordinate system GCS_WGS_1984)

\begin{tabular}{|c|c|c|c|c|c|c|c|}
\hline Country & $\begin{array}{l}\text { Emission } \\
\text { Scenario }\end{array}$ & GCM & $\begin{array}{l}\text { Drought } \\
\text { Frequency }\end{array}$ & $\begin{array}{l}\text { Average } \\
\text { Duration } \\
\text { (months) }\end{array}$ & $\begin{array}{l}\text { Average Peak } \\
\text { Intensity }\end{array}$ & $\begin{array}{c}\text { Average } \\
\text { Magnitude }\end{array}$ & $\begin{array}{c}\% \text { Change in } \\
\text { Average Magnitude } \\
\text { from Observed }\end{array}$ \\
\hline \multirow{7}{*}{ Australia } & Observed & -- & 10 & 17.2 & -1.78 & 14,628 & -- \\
\hline & \multirow{3}{*}{$\begin{array}{c}\text { A1FI } \\
(2003-2050)\end{array}$} & ECHAM4 & 16 & 18.9 & -1.83 & 16,793 & 14.8 \\
\hline & & HADCM3 & 12 & 16.8 & -1.87 & 15,562 & 6.4 \\
\hline & & CSIRO2 & 8 & 17.0 & -1.95 & 15,695 & 7.3 \\
\hline & \multirow{3}{*}{$\begin{array}{c}\text { 450ppm } \\
(2003-2050)\end{array}$} & ECHAM4 & 17 & 21.0 & -1.81 & 17,708 & 21.0 \\
\hline & & HADCM3 & 12 & 16.8 & -1.87 & 15,873 & 8.5 \\
\hline & & CSIRO2 & 8 & 17.0 & -1.96 & 15,760 & 7.7 \\
\hline \multirow{7}{*}{ Brazil } & Observed & -- & 3 & 25.7 & -1.77 & 22,979 & -- \\
\hline & \multirow{3}{*}{$\begin{array}{c}\text { A1FI } \\
(2003-2050)\end{array}$} & ECHAM4 & 8 & 29.1 & -1.87 & 25,388 & 10.5 \\
\hline & & HADCM3 & 9 & 39.0 & -2.09 & 49,596 & 115.8 \\
\hline & & CSIRO2 & 5 & 23.8 & -1.88 & 14,224 & -38.1 \\
\hline & \multirow{3}{*}{$\begin{array}{c}\text { 450ppm } \\
(2003-2050)\end{array}$} & ECHAM4 & 11 & 33.5 & -1.92 & 29,685 & 29.2 \\
\hline & & HADCM3 & 13 & 53.5 & -2.08 & 61,048 & 165.7 \\
\hline & & CSIRO2 & 5 & 23.8 & -1.89 & 14,314 & -37.7 \\
\hline \multirow{7}{*}{ China } & Observed & -- & 4 & 11.3 & -1.76 & 6,976 & -- \\
\hline & \multirow{3}{*}{$\begin{array}{c}\text { A1FI } \\
(2003-2050)\end{array}$} & ECHAM4 & 1 & 8.0 & -1.85 & 7,627 & 9.3 \\
\hline & & HADCM3 & 1 & 8.0 & -1.71 & 6,971 & -0.1 \\
\hline & & CSIRO2 & 1 & 8.0 & -1.73 & 7,133 & 2.3 \\
\hline & \multirow{3}{*}{$\begin{array}{c}\text { 450ppm } \\
(2003-2050)\end{array}$} & ECHAM4 & 1 & 8.0 & -1.87 & 7,703 & 10.4 \\
\hline & & HADCM3 & 1 & 8.0 & -1.72 & 6,996 & 0.3 \\
\hline & & CSIRO2 & 1 & 8.0 & -1.73 & 7,128 & 2.2 \\
\hline \multirow{5}{*}{ Ethiopia } & Observed & -- & 1 & 18 & -1.86 & 6,304 & -- \\
\hline & \multirow{3}{*}{$\begin{array}{c}\text { A1FI } \\
(2003-2050)\end{array}$} & ECHAM4 & 0 & 0 & 0 & 0 & -100.0 \\
\hline & & HADCM3 & 0 & 0 & 0 & 0 & -100.0 \\
\hline & & CSIRO2 & 3 & 15.3 & -1.69 & 5,615 & -10.9 \\
\hline & 450ppm & ECHAM4 & 0 & 0 & 0 & 0 & -100.0 \\
\hline
\end{tabular}




\begin{tabular}{|c|c|c|c|c|c|c|c|}
\hline & $(2003-2050)$ & HADCM3 & 0 & 0 & 0 & 0 & -100.0 \\
\hline & & CSIRO2 & 4 & 13.3 & -1.66 & 4,910 & -22.1 \\
\hline \multirow{7}{*}{ India } & Observed & -- & 5 & 7 & -1.70 & 3,938 & -- \\
\hline & \multirow{3}{*}{$\begin{array}{c}\text { A1FI } \\
(2003-2050)\end{array}$} & ECHAM4 & 0 & 0 & 0 & 0 & -100.0 \\
\hline & & HADCM3 & 0 & 0 & 0 & 0 & -100.0 \\
\hline & & CSIRO2 & 2 & 5.5 & -1.59 & 3,406 & -13.5 \\
\hline & \multirow{3}{*}{$\begin{array}{c}\text { 450ppm } \\
(2003-2050)\end{array}$} & ECHAM4 & 0 & 0 & 0 & 0 & -100.0 \\
\hline & & HADCM3 & 0 & 0 & 0 & 0 & -100.0 \\
\hline & & CSIRO2 & 2 & 5.5 & -1.60 & 3,427 & -13.0 \\
\hline \multirow{7}{*}{ Portugal } & Observed & -- & 13 & 12 & -1.83 & 589 & -- \\
\hline & \multirow{3}{*}{$\begin{array}{c}\text { A1FI } \\
(2003-2050)\end{array}$} & ECHAM4 & 19 & 17 & -2.09 & 1,008 & 71.1 \\
\hline & & HADCM3 & 18 & 16 & -2.02 & 875 & 48.6 \\
\hline & & CSIRO2 & 15 & 11 & -1.88 & 535 & -9.2 \\
\hline & \multirow{3}{*}{$\begin{array}{c}\text { 450ppm } \\
(2003-2050)\end{array}$} & ECHAM4 & 17 & 19.5 & -2.11 & 1,120 & 90.2 \\
\hline & & HADCM3 & 17 & 16 & -2.07 & 886 & 50.4 \\
\hline & & CSIRO2 & 15 & 11 & -1.88 & 535 & -9.2 \\
\hline \multirow{7}{*}{ Spain } & Observed & -- & 4 & 11 & -1.72 & 2,143 & -- \\
\hline & \multirow{3}{*}{$\begin{array}{c}\text { A1FI } \\
(2003-2050)\end{array}$} & ECHAM4 & 12 & 19 & -1.87 & 4,085 & 90.6 \\
\hline & & HADCM3 & 9 & 25 & -1.88 & 5,196 & 142.5 \\
\hline & & CSIRO2 & 7 & 12 & -1.77 & 2,538 & 18.4 \\
\hline & \multirow{3}{*}{$\begin{array}{c}\text { 450ppm } \\
(2003-2050)\end{array}$} & ECHAM4 & 11 & 19 & -1.90 & 4,082 & 90.5 \\
\hline & & HADCM3 & 9 & 25 & -1.95 & 4,454 & 107.8 \\
\hline & & CSIRO2 & 7 & 12 & -1.78 & 2,534 & 18.2 \\
\hline \multirow{7}{*}{ USA } & Observed & -- & 5 & 13.0 & -1.92 & 10,127 & -- \\
\hline & \multirow{3}{*}{$\begin{array}{c}\text { A1FI } \\
(2003-2050)\end{array}$} & ECHAM4 & 5 & 14.0 & -1.80 & 10,452 & 3.2 \\
\hline & & HADCM3 & 5 & 12.4 & -1.81 & 9,472 & -6.5 \\
\hline & & CSIRO2 & 7 & 16.9 & -1.83 & 13,152 & 29.9 \\
\hline & \multirow{3}{*}{$\begin{array}{c}\text { 450ppm } \\
(2003-2050)\end{array}$} & ECHAM4 & 5 & 14.0 & -1.81 & 10,548 & 4.2 \\
\hline & & HADCM3 & 5 & 12.4 & -1.83 & 9,488 & -6.3 \\
\hline & & CSIRO2 & 6 & 18.7 & -1.87 & 13,461 & 32.9 \\
\hline
\end{tabular}

Table 3: SPI-6 drought parameter results for observed data (1955-2002) and future projections

(2003-2050).

\begin{tabular}{|c|c|c|c|c|c|c|c|}
\hline Country & $\begin{array}{l}\text { Emission } \\
\text { Scenario }\end{array}$ & GCM & $\begin{array}{l}\text { Drought } \\
\text { Frequency }\end{array}$ & $\begin{array}{l}\text { Average } \\
\text { Duration } \\
\text { (months) }\end{array}$ & $\begin{array}{l}\text { Average Peak } \\
\text { Intensity }\end{array}$ & $\begin{array}{c}\text { Average } \\
\text { Magnitude }\end{array}$ & $\begin{array}{c}\% \text { Change in } \\
\text { Average } \\
\text { Magnitude from } \\
\text { Observed }\end{array}$ \\
\hline \multirow{7}{*}{ Australia } & Observed & -- & 5 & 32.8 & -1.70 & 26,524 & -- \\
\hline & \multirow{3}{*}{$\begin{array}{c}\text { A1FI } \\
(2003-2050)\end{array}$} & ECHAM4 & 11 & 43.8 & -1.73 & 40,624 & 64.0 \\
\hline & & HADCM3 & 8 & 30.9 & -1.72 & 24,465 & -7.8 \\
\hline & & CSIRO2 & 3 & 30.0 & -1.82 & 28,423 & 7.2 \\
\hline & \multirow{3}{*}{$\begin{array}{c}\text { 450ppm } \\
(2003-2050)\end{array}$} & ECHAM4 & 11 & 43.9 & -1.75 & 40,810 & 53.9 \\
\hline & & HADCM3 & 8 & 31.4 & -1.74 & 24,925 & -6.0 \\
\hline & & CSIRO2 & 3 & 30.0 & -1.84 & 28,756 & 8.4 \\
\hline \multirow{7}{*}{ Brazil } & Observed & -- & 3 & 26.7 & -1.73 & 21,328 & -- \\
\hline & \multirow{3}{*}{$\begin{array}{c}\text { A1FI } \\
(2003-2050)\end{array}$} & ECHAM4 & 4 & 54.8 & -1.83 & 39,956 & 87.3 \\
\hline & & HADCM3 & 4 & 87.3 & -1.73 & 81,634 & 282.7 \\
\hline & & CSIRO2 & 2 & 34.0 & -1.78 & 26,652 & 25.0 \\
\hline & \multirow{3}{*}{$\begin{array}{c}\text { 450ppm } \\
(2003-2050)\end{array}$} & ECHAM4 & 6 & 61.8 & -1.85 & 43,934 & 106.0 \\
\hline & & HADCM3 & 7 & 82.1 & -1.79 & 73,186 & 243.1 \\
\hline & & CSIRO2 & 2 & 35.0 & -1.78 & 27,091 & 27.0 \\
\hline \multirow{7}{*}{ China } & Observed & -- & 1 & 22.0 & -2.11 & 20,499 & -- \\
\hline & \multirow{3}{*}{$\begin{array}{c}\text { A1FI } \\
(2003-2050)\end{array}$} & ECHAM4 & 1 & 23.0 & -1.92 & 19,052 & -7.1 \\
\hline & & HADCM3 & 1 & 22.0 & -1.76 & 15,703 & -23.4 \\
\hline & & CSIRO2 & 1 & 22.0 & -1.84 & 16,606 & -19.0 \\
\hline & \multirow{3}{*}{$\begin{array}{c}\text { 450ppm } \\
(2003-2050)\end{array}$} & ECHAM4 & 1 & 23.0 & -1.93 & 19,135 & -6.7 \\
\hline & & HADCM3 & 1 & 21.0 & -1.77 & 15,440 & -24.7 \\
\hline & & CSIRO2 & 1 & 22.0 & -1.84 & 16,583 & -19.1 \\
\hline \multirow{4}{*}{ Ethiopia } & Observed & -- & 1 & 42.0 & -1.67 & 12,457 & -- \\
\hline & \multirow{3}{*}{$\begin{array}{c}\text { A1FI } \\
(2003-2050)\end{array}$} & ECHAM4 & 0 & 0 & 0 & 0 & -100.0 \\
\hline & & HADCM3 & 1 & 27.0 & -1.59 & 7,594 & -39.0 \\
\hline & & CSIRO2 & 2 & 48.5 & -1.80 & 17,422 & 39.9 \\
\hline
\end{tabular}




\begin{tabular}{|c|c|c|c|c|c|c|c|}
\hline & \multirow{3}{*}{$\begin{array}{c}\text { 450ppm } \\
(2003-2050)\end{array}$} & ECHAM4 & 0 & 0 & 0 & 0 & -100.0 \\
\hline & & HADCM3 & 1 & 26.0 & -1.59 & 7,436 & -40.3 \\
\hline & & CSIRO2 & 2 & 48.5 & -1.81 & 17,619 & 41.4 \\
\hline \multirow{7}{*}{ India } & Observed & -- & 1 & 25.0 & -2.01 & 13,853 & -- \\
\hline & \multirow{3}{*}{$\begin{array}{c}\text { A1FI } \\
(2003-2050)\end{array}$} & ECHAM4 & 0 & 0 & 0 & 0 & -100.0 \\
\hline & & HADCM3 & 0 & 0 & 0 & 0 & -100.0 \\
\hline & & CSIRO2 & 0 & 0 & 0 & 0 & -100.0 \\
\hline & \multirow{3}{*}{$\begin{array}{c}\text { 450ppm } \\
(2003-2050)\end{array}$} & ECHAM4 & 0 & 0 & 0 & 0 & -100.0 \\
\hline & & HADCM3 & 0 & 0 & 0 & 0 & -100.0 \\
\hline & & CSIRO2 & 0 & 0 & 0 & 0 & -100.0 \\
\hline \multirow{7}{*}{ Portugal } & Observed & -- & 6 & 26 & -1.80 & 1,346 & -- \\
\hline & \multirow{3}{*}{$\begin{array}{c}\text { A1FI } \\
(2003-2050)\end{array}$} & ECHAM4 & 7 & 37 & -2.13 & 2,472 & 83.6 \\
\hline & & HADCM3 & 6 & 37 & -2.01 & 2,143 & 59.2 \\
\hline & & CSIRO2 & 4 & 25 & -1.94 & 1,321 & -1.86 \\
\hline & \multirow{3}{*}{$\begin{array}{c}\text { 450ppm } \\
(2003-2050)\end{array}$} & ECHAM4 & 7 & 42 & -2.22 & 2,820 & 109.5 \\
\hline & & HADCM3 & 8 & 34 & -1.98 & 2,014 & 49.6 \\
\hline & & CSIRO2 & 4 & 23 & -1.94 & 1,270 & -5.65 \\
\hline \multirow{7}{*}{ Spain } & Observed & -- & 4 & 22 & -1.69 & 4,039 & -- \\
\hline & \multirow{3}{*}{$\begin{array}{c}\text { A1FI } \\
(2003-2050)\end{array}$} & ECHAM4 & 3 & 56 & -2.00 & 13,917 & 244.6 \\
\hline & & HADCM3 & 2 & 76 & -2.11 & 17,811 & 341.0 \\
\hline & & CSIRO2 & 2 & 42 & -1.80 & 7,925 & 96.2 \\
\hline & \multirow{3}{*}{$\begin{array}{c}\text { 450ppm } \\
(2003-2050)\end{array}$} & ECHAM4 & 4 & 55 & -1.95 & 12,914 & 219.7 \\
\hline & & HADCM3 & 3 & 52 & -1.96 & 12,468 & 208.7 \\
\hline & & CSIRO2 & 2 & 42 & -1.79 & 7,904 & 95.7 \\
\hline \multirow{7}{*}{ USA } & Observed & -- & 4 & 24 & -1.67 & 24,321 & -- \\
\hline & \multirow{3}{*}{$\begin{array}{c}\text { A1FI } \\
(2003-2050)\end{array}$} & ECHAM4 & 2 & 30.0 & -1.82 & 20,471 & -15.8 \\
\hline & & HADCM3 & 2 & 35.5 & -1.75 & 54,589 & 124.5 \\
\hline & & CSIRO2 & 3 & 36.0 & -1.73 & 46,092 & 89.5 \\
\hline & \multirow{3}{*}{$\begin{array}{c}\text { 450ppm } \\
(2003-2050)\end{array}$} & ECHAM4 & 2 & 30.0 & -1.85 & 20,594 & -15.3 \\
\hline & & HADCM3 & 2 & 35.5 & -1.77 & 54,708 & 124.9 \\
\hline & & CSIRO2 & 3 & 36.0 & -1.74 & 46,245 & 90.1 \\
\hline
\end{tabular}

Table 4: SPI-12 drought parameter results for observed data (1955-2002) and future

projections (2003-2050).

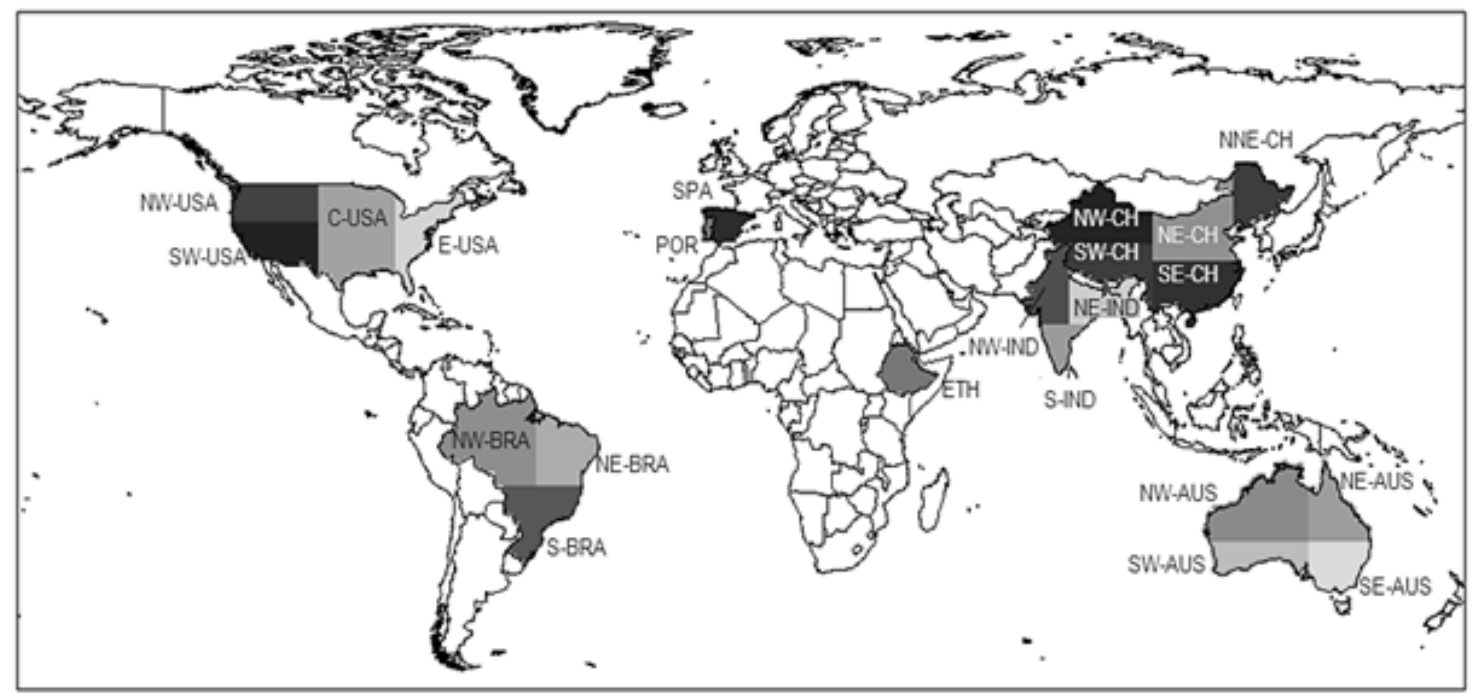

Figure 1 

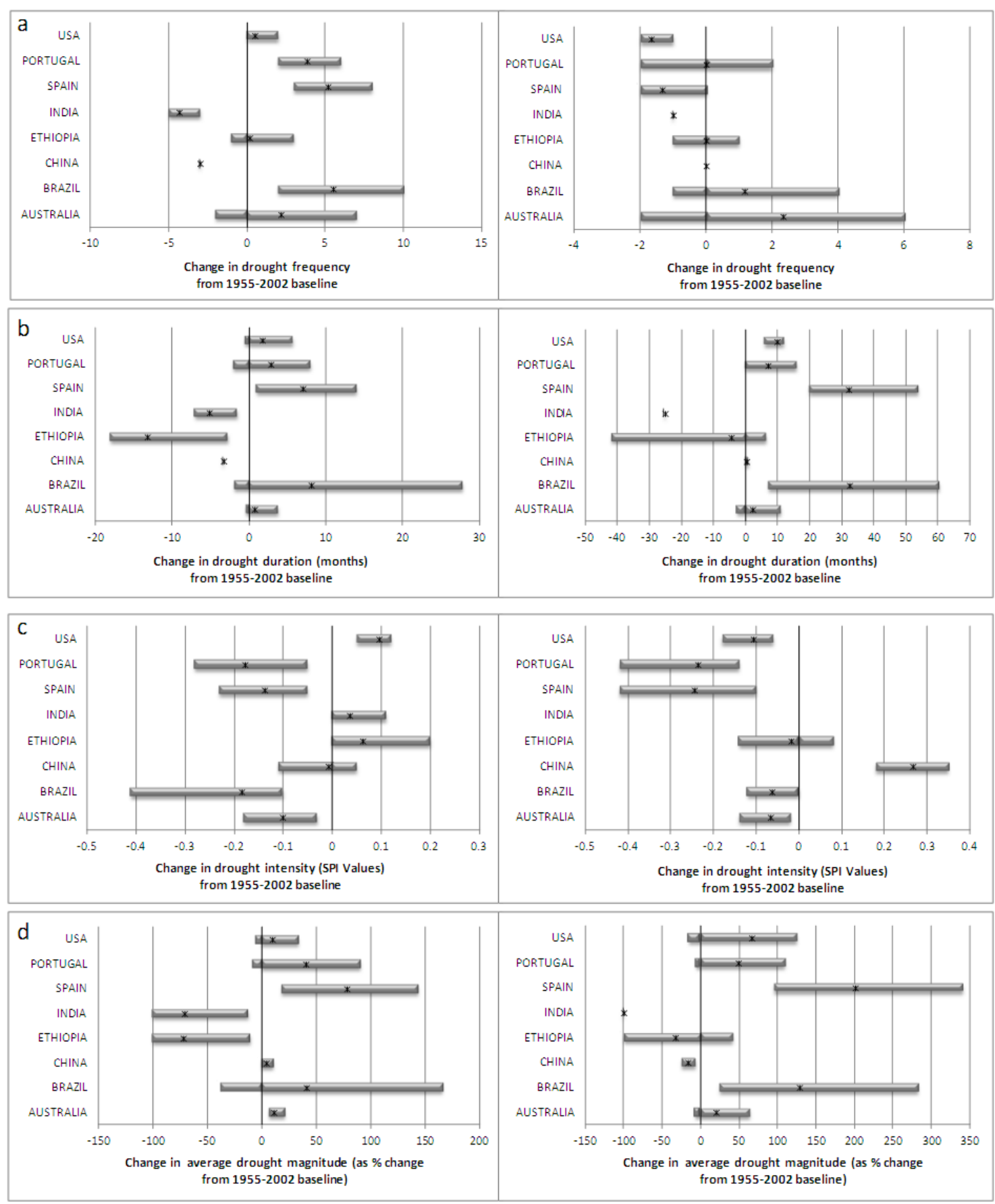

Figure 2 

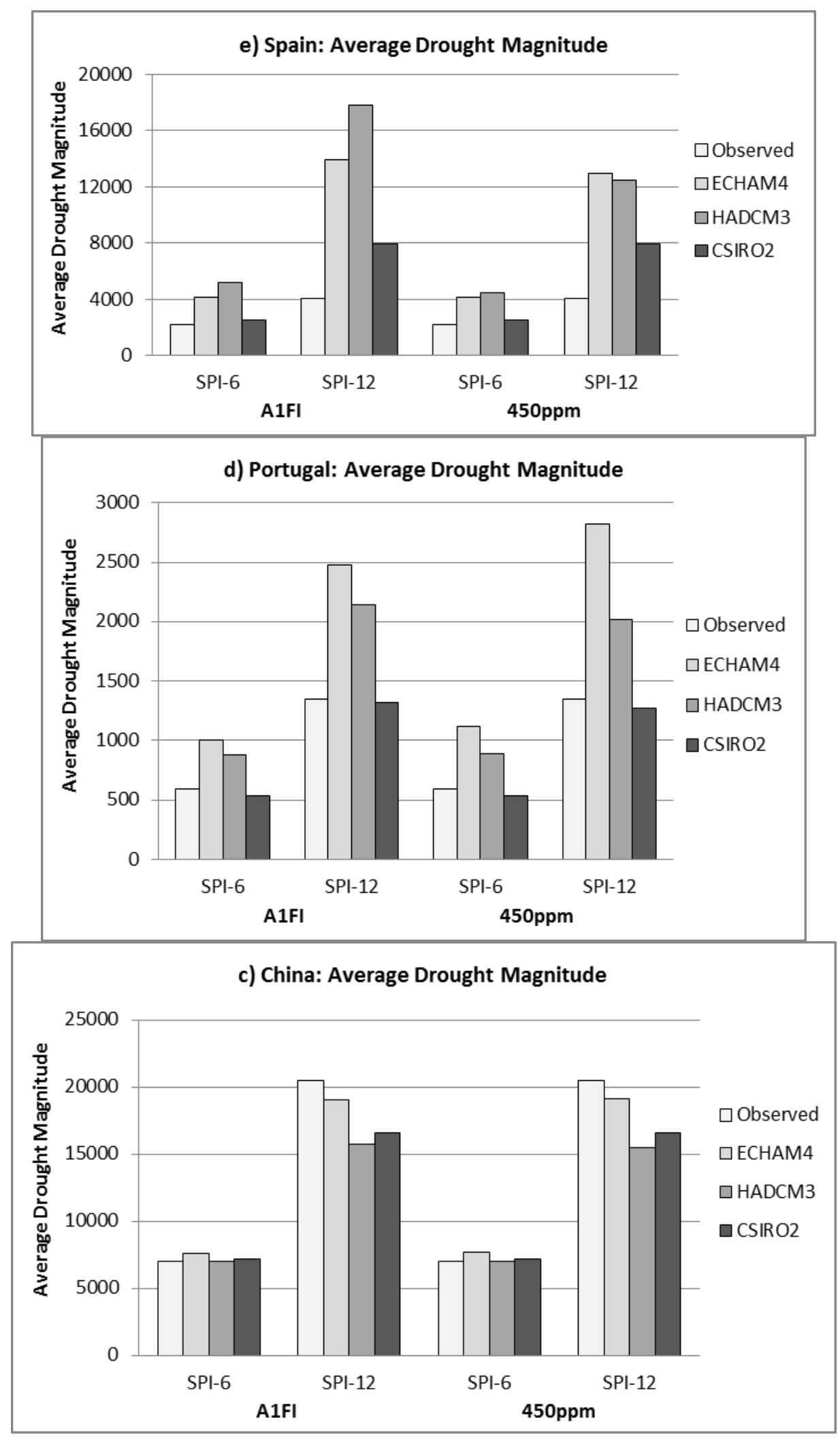


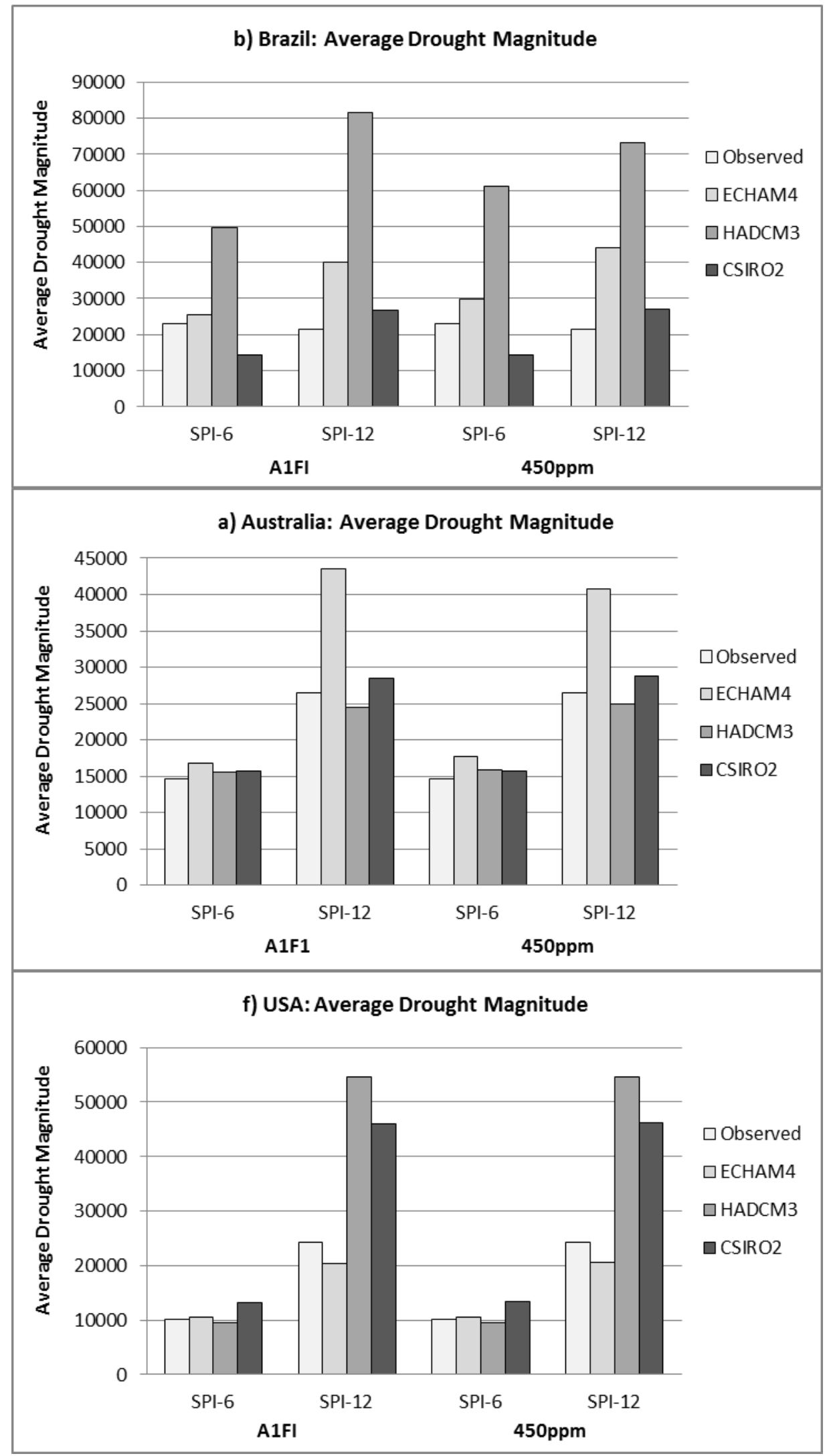

Figure 3 